Journal of Education and Educational Development

8(1), 218-234, 2021

DOI: http://dx.doi.org/10.22555/joeed.v8i1.114

\title{
Assessment Literacy of Prospective Teachers in Distance Mode of Education: A Case Study of Allama Iqbal Open University, Islamabad
}

\author{
Zarina Akhtar \\ International Islamic University, Pakistan \\ Sajjad Hussain \\ University of Swat, Pakistan \\ Nasir Ahmad \\ University of Swat, Pakistan
}

\begin{abstract}
Pre-service teacher education comprises essential courses to prepare prospective teachers for effective classroom assessment practices. The study analyzes study material on students' assessment and assessment literacy of prospective teachers is investigated which require close attention of policy makers and practitioners for authentic assessment in classrooms. A sequential triangulation research design, using mix-method approaches, has been used for this research. All distance education students studying in B.Ed. and M.Ed. programs at Allama Iqbal Open University, Islamabad make the target population of the study. Through random sampling techniques, a sample of 344 prospective teachers and 18 teacher educators constitute the sample group. Results indicate that the study material satisfied the standards as stipulated in the National Professional Standards for Teachers in Pakistan; however, the assessment literacy of prospective teachers was found unsatisfactory. Furthermore, it was revealed that students' low motivation, low interaction between tutors and prospective teachers, and traditional approaches and beliefs were found to be the areas requiring urgent attention with regard to reforms in assessment. The presentation of study materials is found to be less engaging with no clearly specified road map for implementation in classrooms. Assessment practices by teacher educators included only summative approaches.
\end{abstract}


Therefore, it is recommended that the study materials may be re-designed to ensure that it leads towards prospective teachers' assessment literacy.

Keywords: assessment literacy, assessment standards, distance education, learning experiences, prospective teachers

\section{Introduction}

Distance mode of education has been gaining increasing prominence for the last three decades in many disciplines (Simonson, \& Seepersaud, 2018). There are numerous reasons for this increase, including extensive access to the remote and far plunge areas of a country, where formal educational institutions are not operating. Furthermore, the recent trends of Massive Open Online Courses (MOOCs) in distance learning have provided further access to thousands and millions of students across the globe. It appears to be an opportunity for millions of aspiring students who otherwise may not be able to access formal face-to-face formats of education for various reasons (Clarke, 2013). Similarly, the current Covid-19 has proved the worth and importance of distance and online learning even in formal mode of education during the pandemic (Raaper \& Brown, 2020).

Besides the importance of distance education, its quality has always been a concern among the professionals (Jung, 2012). The model is designed to satisfy the needs of learning through extensive reading materials, tutorial support system, face-to-face workshops, assignments and traditional paper pencil tests examination system, but, studies shows concerns on its quality aspects (Akhter, 2014; MejíaMadrid \& Molina-Carmona, 2016). Likewise, Ali and Ahmad (2011) and Simonson et al. (2014) studied students' satisfaction about distance education mode offered by AIOU; and concluded that tutors and students were satisfied with the program that they were attending. The results of these studies also added that the study materials were up-to-date, relevent and according to the market needs. They found that similar to formal mode of education, there were frequent interactions between the tutors and the students. The tutors were found competent and devoted to their work and the courses of distance education were found regularly evaluated.

The establishment of Allama Iqbal Open University (AIOU) since its inception in 1974 is offering teacher education programs and successfully meeting teachers' professional needs at school level in Pakistan. It is much popular in 
remote and backward areas where formal universities, their campuses and enough colleges are not available; however, its popularity and effectiveness is neither less in well-developed areas of Pakistan as it is positively contributing into students' academic performances and teachers' professional competences (Sabir et al. 2014; Shahzad, 2017). In the discipline of teacher education, AIOU offers different teacher education programs such as Bachelor of Education (B.Ed.), Master of Education (M.Ed.), Associate Degree in Education, (ADE), Professional Teaching Certificate (PTC), Certificate in Teaching (CT) (Jumani, 2007; Shahzad, 2017). Furthermore, in all these programs, particularly in B.Ed., ADE and M.Ed., at least one course is offered to the participants around the themes on assessment and evaluation in classrooms. These courses are offered to make the prospective teachers literate in classroom assessment techniques (Jumani \& Zai, 2009; Simonson et al., 2014). The courses are comprised the fundamental concepts in assessment including, definition of key terms of assessment, principles of sound assessment, assessment tools, processes of tool development, psychometric properties of assessment tools, feedback and its types, grading students', communication of assessment results and ethical consideration in students' assessment. These courses intend to develop the assessment literacy of the prospective teachers (Hussain et al., 2019).

Assessment literacy is the set of knowledge, skills and competence of an individual to distinguish between appropriate and inappropriate methods of assessment. Subsequently, this literacy improves teachers' instruction and students' learning (Ng et al., 2020; Pratiwi et al., 2020). Popham (2011) believes that assessment literacy is an individual's understanding of the basic concepts and procedures of assessment, necessary for the educational decisions based on assessment results. Similarly, assessment literacy also relates to the designing of assessment tools, collecting the relevant data with appropriate tools, analyzing and interpreting the collected data and using the assessment results in meaningful ways (Yamtim \& WongWanich, 2014). Students' assessment literacy enables them to understand the marking criteria and dimensions deemed important for high marks thereby yielding positive impact on their academic achievement (Hussain et al., 2017).

In nutshell, authors like Chaney et al. (2007), Davies et al. (2001), Jung (2012) and $\mathrm{Xu}$ and Brown (2016) have different point of views regarding the effectiveness and quality of distance education; therefore, this study intends to 
investigate the extent to which the teachings of assessment and evaluation prepares the prospective teachers for the future teaching responsibilities and that these courses contribute into the assessment literacy of prospective teachers in distance teacher education in Pakistan.

\section{Research Questions}

1. What is the quality of the study materials on assessment and to what extent are these materials are in congruence with assessment literacy standards?

2. What is the assessment literacy level of prospective teachers in distance education?

3. What are the major learning problems of distance education students regarding assessment?

\section{Literature Review}

Assessment literacy has been identified the most foundational competencies ofteachers. Researchers like Hussain (2017), Popham(2011), Taylor(2009) etc., have studied assessment literacy from teaching learning process in relation to different perspectives and fields. All these researchers were agreed on the importance of teachers' assessment literacy as it ensures the effective implementation of teachers' instructional plan. Popham (2011) confessed his ignorance in the initial phase of his professional life about assessment knowledge and skills. He believed that a teacher cannot lead his instructional plan effectively without assessment literacy, it enables them to use assessment for students' learning, and modifying his/her teaching style and leads the learners towards their learning targets.

Hussain (2017) in his $\mathrm{PhD}$ dissertation concentrated on the assessment literacy of teacher educators. He concluded that teacher educators have low understanding in developing reliable and valid assessment tools; that also create a strong question that if they have low level of understanding what will be the situation with their students (the prospective teachers)? Similarly, Hussain et al. (2019) while studying the assessment practices and challenges at secondary school level in Pakistan concluded that teachers at secondary level only concentrated on the summative assessment tools, where they are using assessment of learning only and overlook assessment as learning and assessment for learning. This also leads to 
other important conclusions that teachers have low level or even unaware about the remaining two strategically usages of assessment.

Furthermore, numerous studies have concluded that in test construction, teachers have low level competencies on which these studies concluded that even in United States of America and like other technologically advanced countries, teachers concentrated on low level cognitive questions that are knowledge, and understanding (Semahegn et al., 2019). Similarly, another study concluded that nearly $13 \%$ of students fail in final term examinations due the faulty questions designed by the teachers. Therefore, the Oregon state education department concluded that for designing a valid test one has to master three important areassubject mastery, assessment knowledge and different tests formats including its uses, merits and drawbacks (Oriondo \& Dallo-Antonio, 1984).

For this purpose, government non-government institutions and HEIs are investing in the uplift of teachers' assessment literacy and skills. A study conducted by Kruse et al. (2020) concluded that teachers were trained in assessment as teaching, assessment and learning strategies in teaching learning process was effective. Furthermore, the study also revealed that assessment in itself is not delimited to the assessment of students' learning, but through feedback practices, Classroom Assessment Techniques (CAT) and rigorous practices on test construction (MCQs, Short answers, Long answers, its marking, rubric designing) could lead the teachers to achieve the desired targets of assessment in teaching learning process.

Like the advance world, Pakistan has also worked on the national professional standards for teachers in Pakistan. These are the 10 standards, where on $5^{\text {th }}$ number, a teacher is supposed to be competent in the use of assessment. Therefore, in all pre-service educational programs one or two foundational courses on assessment measurement and evaluation are taught to prospective teachers with the aim to prepare them for the gigantic task of students' assessment. In this regard, Allama Iqbal Open University also offers courses on assessment and measurement to the prospective students through their distance education mode to satisfy the needs of prospective teachers in their respective jobs. 


\section{Methodology}

\section{Research Design}

A mixed method research design was adopted for the study. The qualitative data collected by document analysis in this regard the study material was assessed. The interviews were conducted to explore the assessment literacy of tutors. The quantitative data was collected from prospective teachers through Survey named as Assessment Literacy Questionnaire (ALQ). The interviews and survey was conducted at the end of the course "classroom assessment".

\section{Sample}

The population of the study was tutors and prospective teacher from distance education program B.Ed and M.Ed of AIOU from district Swat and Mardan. Eighteen tutors and 344 prospective teachers were selected through simple random sampling technique from seven stations during academic session 2015-2016.

\section{Instrument}

Three instruments were used to collect data. The first content analysis was done by using assessment standards used by American Federation of Teachers (AFT) and National Council of Measurement in Education (NCME). The instrument included components representing the seven standards of AFT and NCME. The content analysis was carried out on the selected courses of Educational Measurement and Evaluation (Code 6507). This course included nine units on students' assessment:1) An introduction to measurement and evaluation, 2) Qualities of a good test, 3) Integrating objectives with evaluation measurement, 4) Types of tests, 5) Methods of measurement, 6) Planning and administration for classroom testing, 7) Marking and reporting, 8) School testing trends and issues, and 9) Statistics used in measurement and evaluation. These units were analyzed using the assessment standards for teachers' competence in assessment used by the American Federation of Teachers (AFT) and National Council of Measurement in Education (NCME). The materials were assessed keeping in view the relevance to the seven standards from AFT and NCME. Furthermore, the materials were analyzed keeping in view the sequential presentation, up-dated and research based knowledge having full references, and the appropriateness of the learning experiences recommended for students. 
The survey ALQ was based on seven statements related to the perceptions of prospective teachers about assessment techniques they have learned and used by their teachers. This instrument was first exposed to pilot testing to measure the reliability co-efficient of the instrument, and contextual compatibility. The reliability co-efficient was .73 . The researchers made necessary changes in the instrument for adopting it to the changed context.

Interviews with the tutors focused on their perceptions and experiences of the issues and challenges related to the material on assessment, the required facilities, and competence level of prospective teachers in assessment. These interviews were individual in nature and notes were taken during the interview as most of the respondents were not permitting to record the interviews. Using constant comparison method (Strauss \& Corbin, 1994), data was first coded followed by generating major themes. The real names of the participants were not used in data. They were named as participant 1, 2, 3 and so on.

\section{Findings}

The results of document analysis were presented along with the factors observed in the study materials. Four factors were studied and the nature of the contents was structured into three levels as shown in table.

\section{Table 1}

Detail of the Factors Observed During Document Analysis

\begin{tabular}{|c|c|c|c|}
\hline Sequential presentation & $\begin{array}{l}\text { Research- } \\
\text { orientation }\end{array}$ & $\begin{array}{l}\text { Publication } \\
\text { year }\end{array}$ & Learning experiences \\
\hline $\begin{array}{l}\text { a. From easy to complex } \\
\text { with direct relevance }= \\
\text { Strong Sequence }\end{array}$ & $\begin{array}{l}\text { Empirical Research } \\
\text { Articles = ERA }\end{array}$ & Before 2000, & $\begin{array}{l}\text { Recommended } \\
\text { Practices }\end{array}$ \\
\hline $\begin{array}{l}\text { b. Average level sequence } \\
\text { and fluctuation in study } \\
\text { materials = Moderate } \\
\text { Sequence }\end{array}$ & $\begin{array}{l}\text { b. Review Papers }= \\
\text { RP }\end{array}$ & $\begin{array}{l}\text { b. Between } 2001 \\
\text { to } 2010\end{array}$ & $\begin{array}{l}\text { b. Practice on } \\
\text { Assessment }\end{array}$ \\
\hline $\begin{array}{l}\text { c. Most of the materials } \\
\text { were irrelevant = Low } \\
\text { Sequence }\end{array}$ & $\begin{array}{l}\text { c. Extraction from } \\
\text { Books = EB }\end{array}$ & $\begin{array}{l}\text { c. Between } 2011 \\
\text { to } 2016\end{array}$ & $\begin{array}{l}\text { c.No recommended } \\
\text { Learning experiences }\end{array}$ \\
\hline
\end{tabular}




\section{Table 2}

Document Analysis of Study Materials on Assessment Standards

\begin{tabular}{|c|c|c|c|c|c|}
\hline $\begin{array}{l}\text { Standards of AFT and } \\
\text { NCME }\end{array}$ & Chapters & $\begin{array}{c}\text { Sequential } \\
\text { presentation }\end{array}$ & $\begin{array}{l}\text { Research- } \\
\text { orientation }\end{array}$ & $\begin{array}{c}\text { Publication } \\
\text { year }\end{array}$ & $\begin{array}{c}\text { Learning } \\
\text { experiences }\end{array}$ \\
\hline $\begin{array}{l}\text { Choosing assessment } \\
\text { methods appropriate for } \\
\text { instructional decisions }\end{array}$ & 2,4 & $\begin{array}{l}\text { Moderate } \\
\text { sequence }\end{array}$ & EB & $\mathrm{A}$ & $\mathrm{C}$ \\
\hline $\begin{array}{l}\text { Developing assessment } \\
\text { methods appropriate for } \\
\text { instructional decisions }\end{array}$ & 3,5 & $\begin{array}{c}\text { Low } \\
\text { sequence }\end{array}$ & $\mathrm{RP}$ & A & $\mathrm{C}$ \\
\hline $\begin{array}{l}\text { Administering, scoring } \\
\text { and interpreting the } \\
\text { results }\end{array}$ & 6,7 & $\begin{array}{l}\text { Moderate } \\
\text { sequence }\end{array}$ & EB & A & $\mathrm{B}$ \\
\hline Using assessment results & & & No materials & & \\
\hline $\begin{array}{l}\text { Developing valid pupil } \\
\text { grading procedures }\end{array}$ & 7 & $\begin{array}{l}\text { Moderate } \\
\text { sequence }\end{array}$ & EB & A & $\mathrm{B}$ \\
\hline $\begin{array}{l}\text { Communicating } \\
\text { assessment results to } \\
\text { students, parents }\end{array}$ & 7 & $\begin{array}{c}\text { Low } \\
\text { sequence }\end{array}$ & EB & A & $\mathrm{C}$ \\
\hline $\begin{array}{l}\text { Recognizing unethical, } \\
\text { illegal, and otherwise } \\
\text { inappropriate assessment } \\
\text { methods }\end{array}$ & 1 & $\begin{array}{l}\text { Low } \\
\text { sequence }\end{array}$ & $\mathrm{RP}$ & A & $\mathrm{C}$ \\
\hline
\end{tabular}

The document analysis of the Educational Measurement and Evaluation (Code 6507) course book was done keeping in view four factors i.e., sequential presentation of the learning materials, extraction of the learning materials from research perspectives, year of publication, and the learning experiences recommended for students' active leaning in the subject. The study materials were found not satisfactory as the presentation of study materials had weak connection and sequence which may negatively affect students' interest in reading and learning. The study materials lacked information for prospective teachers on using assessment results for different educational and informational purposes. Modern concepts such as assessment for learning, assessment as learning, integrated, performance-based and authentic assessment were also not found in the study materials. Furthermore, rubric, portfolio, projects, and other such alternative assessment tools were found missing in the study materials. The ethical considerations in assessment were not properly presented in a unit, they were found scattered in the content. Furthermore, 
these materials were also lacking the practicing guidelines that how the ethical considerations may be followed during assessment practices at classroom and individual level.

The sources of the extracted study materials were mostly from books. Research oriented materials were not presented except some review papers on developing assessment methods and ethical considerations in assessment. Furthermore, all the study materials were published before the year 2000 with the latest published work published in 1999. Similarly, the materials lacked in offering prospective teachers activities and examples to put theory in practice. The material on assessment literacy lacked practical work for prospective teachers. The tutors assessed them on assignment which was improper for authentic assessment of assessment literacy.

These results are aligned with the results of Hussain et al. (2017) and Kippers et al. (2018) where they claimed that teachers have low literacy in the designing of assessment. Furthermore, teachers frequently follow summative assessment practices as they understand it more than formative assessment practices. The results of current study reveal that ethical considerations in assessment were not properly presented due to which teachers show negligence in students' assessments that negatively influence the academic performances of students (Akhter, 2015). Likewise, the outdated materials do not allow the student teachers to learn about the emerging concepts of assessments (Chang et al., 2012).

\section{Table 3}

Assessment Literacy of Prospective Teachers

\begin{tabular}{|c|c|c|c|c|c|}
\hline Standards of AFT and NCME & Mean & SD & df & $\chi 2$ & $\mathbf{p}$ \\
\hline $\begin{array}{l}\text { Choosing assessment methods appropriate for } \\
\text { instructional decisions }\end{array}$ & 2.351 & .965 & & & \\
\hline $\begin{array}{l}\text { Developing assessment methods appropriate for } \\
\text { instructional decisions }\end{array}$ & 2.655 & .987 & 04 & 23.59 & .002 \\
\hline Administering, scoring and interpreting the results & 2.862 & .894 & & & \\
\hline Using assessment results & 1.782 & 1.29 & & & \\
\hline Developing valid pupil grading procedures & 2.873 & .761 & & & \\
\hline Communicating assessment results to students, parents & 1.666 & .322 & & & \\
\hline $\begin{array}{l}\text { Recognizing unethical, illegal, and inappropriate } \\
\text { assessment methods }\end{array}$ & 1.788 & .688 & & & \\
\hline
\end{tabular}


The mean scores of prospective teachers on assessment literacy reflected that majority of prospective teachers had low assessment literacy. The mean scores 2.35 as per scale shows that the prospective teachers have lowest understanding in using assessment results. The mean score, 1.66, about communicating assessment results, show that students were weak in this skill. Similarly, the mean score 1.78, about ethical consideration in assessment, show that the understanding about this aspect was weak. However, the mean scores, 2.35, 2.65, 2.86 and 2.86 about choosing appropriate methods for instructional decisions, developing assessment methods, administering and scoring and interpreting results and develop people grading procedure respectively showed that prospective teachers have average assessment literacy about these aspects of assessment which needs improvement. The chi square value 23.59, which is significant at .002, also explains that these results are significant from the perspective of respondents whose low assessment literacy has been recorded.

These results are quite similar to the document analysis results. The results show that the assessment literacy of prospective teachers was low and these results were supported by the results of Hussain et al. (2018). Due to the absence of proper training and education in students' assessment, teachers were unable to assess students' performance objectively (Deluca et al., 2016). The low assessment literacy is a persistent problem not only in school teachers, but also in university teachers; therefore Shams and Iqbal (2019) recommended a strong traning program for the teachers of all levels to improve their assessment literacy.

\section{Interview Results}

After thorough interviews with tutors of distance education of AIOU, their responses were presented below; 


\section{Figure 1}

Interview Theme on Study Materials \& Ethics in Assessment and its Categories

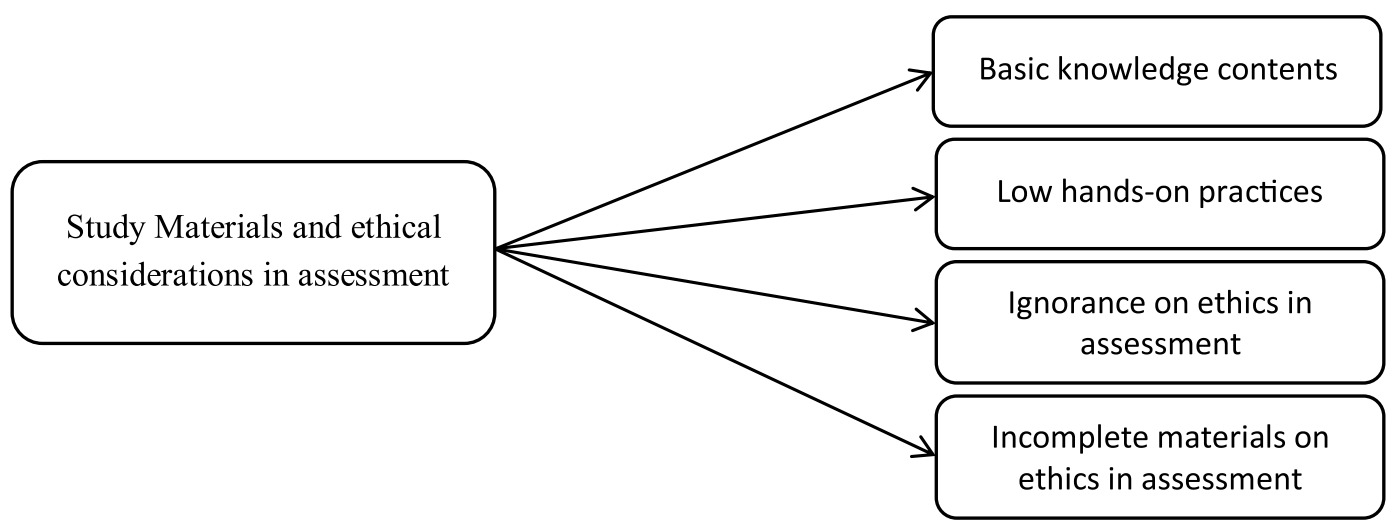

All the respondents were of the opinion that the study materials given to prospective teachers are productive as well as enough to educate the prospective teachers in the field of classroom assessment. However, most of the materials cover the theoretical aspects of assessment and the exercises and students' assignments only cannot satisfy the hands-on practices in the subject of assessment as there is dire need of rigorous hands-on exercises in tests' construction and other aspects of assessment.

On the question of ethical considerations in students' assessment, the respondents were found silent which reflects their ignorance regarding ethics and legal aspects of students' assessment. They viewed that the available materials on ethical considerations in classroom assessment are not enough and even not followed. Furthermore, the scattered nature of materials on ethics in assessment was also a reason of the low understanding of the respondents. Only one respondent stated:

"Assessment and ethics are closely connected concepts; one is incomplete without the other."

Distance mode of education is dependent on the study materials provided to students as these materials are the single sources for students' education of the subject and discipline. If proper study materials are not provided to students on the 
entire fundamental, modern and required aspect of a subject, the students will not be competent in that subject. Olt (2002) while discussing the ethical considerations in distance and online learning concluded that cheating in exams, taking support from other students and such other mechanisms used by students are against the ethics in assessment from teachers' perspective. Likewise, Pope, et al. (2009) viewed the surprised tests, making educational decisions of students on ill made assessment tools, biased marking and using standardized tests without informed consents are some of the crucial unethical practices often teachers were found during students' assessment. The results of the current study revealed that teachers are unaware about the ethical and unethical practices in students' assessment.

\section{Figure 2}

Interview Themes on the Causes of Low Assessment Literacy of Prospective Teachers and its Categories

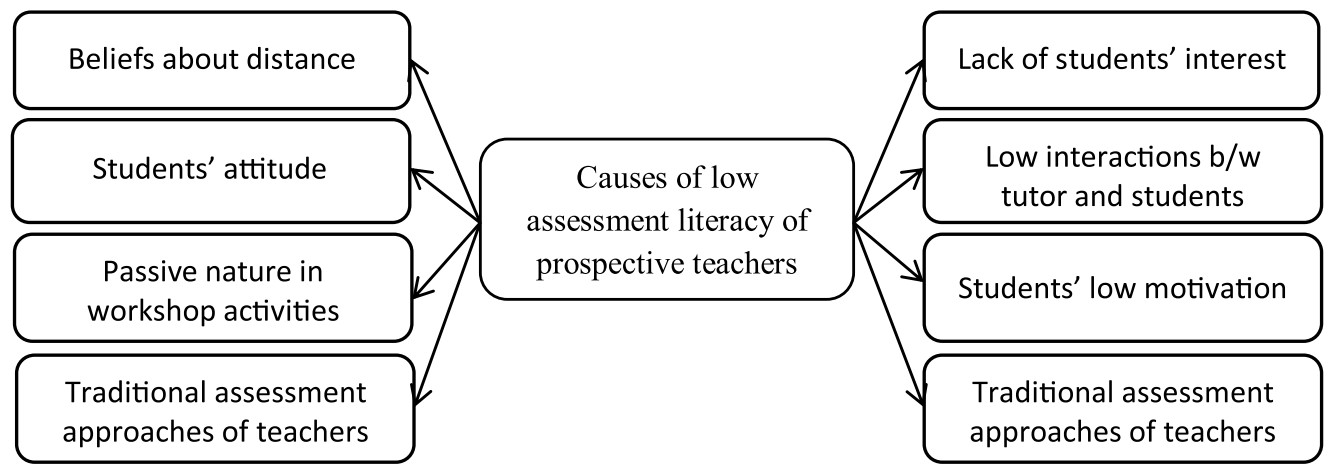

In response of low assessment literacy of prospective teachers' different responses were collected. The above figure represents the major causes of low assessment literacy. These causes were also found by Reaper and Brown (2020). They found during the pandemic the activities are not conducted as in face to face mod so teachers use traditional assessment approaches which do not fit for distance learning mod students. Shazad (2017) found students low motivation and lack of competition create lack of interest for learning in students. The respondents were of the view that assessment demands far more practical experiences than just to prepare the assignment in the course. Further the students enrolled in distance education mod are busy somewhere and found less time to interact with the teacher so one cause of their low assessment literacy was less interaction between tutor and tutee. Students are merely interested in obtaining a degree than the learning which 
comes with the degree. Most of the time they have no contact with their tutors, and they do not raise questions even in the workshops arranged by AIOU for students to clear any misconception that they may have regarding a topic understudy. One respondent stated:

"Prospective teachers are limited to the bookish knowledge in assessment; they have no access to learning experiences such as scoring tests, grading students' assessment, preparing tests/question papers and other assessment tools which is the most important factor in low assessment literacy of prospective teachers".

Majority of the respondents were also of the view that most of the prospective teachers are enrolled for degree acquisition only; they have traditional beliefs regarding distance learning education which also negatively influence their performances. On the emerging demands in students' assessment at schools. The respondents were of the view that assessment results are used now-a-days for different instructional and administrative decisions. One participant said:

"Currently assessments in schools are frequent and mostly collect data through alternative assessment tools such as portfolio, projects, reflective notes, anecdotes and classroom observations. More knowledge and skills are required in scoring alternative assessment tools, but these assessment courses are unable to prepare the prospective teachers for the field."

On classroom assessment, a respondent stated:

"Frequent classroom tests and examinations leads to negative competition, anxiety and unnecessary stress and tension among students which further demands the teachers to cope with the situations."

On the question of special concerns on students' assessment for prospective teachers' a participant was of the view that,

"Prospective teacher need to focus on alterative assessment tools, special care in scoring subjective questions in tests (use rubrics), the language and verbs used in question papers also need to tackle not only knowledge 
level answers but also understanding and application. Furthermore, ethical considerations and the appropriateness in the selection of assessment tool are also important to be taking into consideration."

The same type of responses was found by Jumani (2007). He describe prospective teachers need to learn how to construct different types of test questions and how to assess. On the learning experiences in students' assessment the respondents were of the view that writing assignment and giving examinations are not learning experiences; study materials of AIOU are missing appropriate learning experiences for prospective teachers in learning assessment skills.

\section{Conclusion and Recommendations}

Assessment literacy is the set of knowledge, skills and competence which enable a teacher to assess effectively the learning of learners. On the basis of data analysis it is concluded that the content of the assessment course oversees proper presentation and proper sequence. The content does not have topic on the how to use results of assessment for different purposes. Moreover, important concepts such as assessment for learning, assessment as learning, integrated, performance-based and authentic assessment, rubric, portfolio, projects, and other such alternative assessment are not available. Ethical considerations in assessment are not properly presented in the content of the course. The materials lacked in offering prospective teachers' activities and examples to put theory in practice.

It is recommended to the curriculum developers that some concepts of assessment which ensure authentic learning, for instance, assessment as learning, performance-based and authentic assessment, rubric, portfolio, projects, and other such alternative assessments; all these may be properly presented in the assessment courses. They may be taught practically so that the concepts are properly ingrained in the minds of prospective teachers. The course on assessment may have research based content for understanding various concepts of assessment. The learners may study the content in different contexts and extract learning for their own uses and needs. Ethics play an essential role in the process of teaching and learning. Students get discouraged when ethics are not followed in assessment. Hence, the courses may have applicable content on the ethical consideration while doing assessment. 


\section{References}

Akhter, N. (2014). Satisfaction of distance learners with the quality of teacher education in Pakistan: A case study of AIOU, Islamabad. Journal of Educational Research, 17(1), $1-13$.

Akhter, N. (2015). Perceptions of academicians regarding assessment process of distance teacher education courses in Pakistan. Pakistan Journal of Commerce and Social Sciences, 9(1), 248.

Ali, A., \& Ahmad, I. (2011). Key factors for determining students' satisfaction in distance learning courses: A study of Allama Iqbal Open University. Contemporary Educational Technology, 2(2), 118-134.

Chang, C. C., Tseng, K. H., \& Lou, S. J. (2012). A comparative analysis of the consistency and difference among teacher-assessment, student self-assessment and peerassessment in a web-based portfolio assessment environment for high school students. Computers \& Education, 58(1), 303-320.

Clarke, T. (2013). The advance of the MOOCs (massive open online courses) The impending globalization of business education?. Education + Training, 55(4/5), 403-413.

Hussain, S. (2017). Relationship of Teacher Educators 'Assessment Literacy and Classroom Assessment Practices with their Students'Academic Achievement (Doctoral dissertation). International Islamic University, Islamabad.

Hussain, S., Kayani, M, M., \& Akhtar, Z. (2017). An exploratory study of assessment literacy of teacher educators in Pakistan. Journal of Applied Enviornmental and Biological Sciences , 8(12), 148-152.

Hussain, S., Kayani, M. M., \& Akhtar, Z. (2018). A correlational study on teacher educators' assessment literacy and their students' academic achievement. Pakistan Journal of Education, 35(3).

Hussain, S., Shaheen, N., \& Ahmad, N. (2019). Teachers' classroom assessment practices: challenges and opportunities to classroom teachers in Pakistan. Dialogue, 14(1), 88 .

Jumani, N. B. (2007). Study on the competencies of the teachers trained through distance education in Pakistan. (Unpublished post-doctoral research). http://eprints. hec. gov. pk/3517/1/DR_NABI_BUX_JUMANI_post_doc_rport.pdf.

Jumani, N. B., \& Zai, Z. I. Y. (2009). Distance teacher education in Pakistan. Quarterly Review of Distance Education, 10(4), 381.

Jung, I. (2012). Asian learners' perception of quality in distance education and gender differences. International Review of Research in Open and Distributed Learning, 13(2), 1-25. 
Kippers, W. B., Wolterinck, C. H., Schildkamp, K., Poortman, C. L., \& Visscher, A. J. (2018). Teachers' views on the use of assessment for learning and data-based decision making in classroom practice. Teaching and Teacher Education, 75, 199213.

Kruse, L., Impellizeri, W., Witherel, C. E., \& Sondergeld, T. A. (2020). Evaluating the impact of an assessment course on preservice teachers' classroom assessment literacy and self-efficacy. Mid-Western Educational Researcher, 32(2).

Mejía-Madrid, G., \& Molina-Carmona, R. (2016). Model for quality evaluation and improvement of higher distance education based on information technology. In Proceedings of the Fourth International Conference on Technological Ecosystems for Enhancing Multiculturality (pp. 1171-1177).

Oriondo, L. L., \& Dallo-Antonio, E. M. (1984). Evaluating Educational Outcomes: Tests, Measurement and Evaluation. Rex Book Store.

Olt, M. R. (2002). Ethics and distance education: Strategies for minimizing academic dishonesty in online assessment. Online Journal of Distance Learning Administration, 5(3), 1-7.

Pope, N., Green, S. K., Johnson, R. L., \& Mitchell, M. (2009). Examining teacher ethical dilemmas in classroom assessment. Teaching and Teacher Education, 25(5), 778782 .

Popham, W. J. (2011). Assessment literacy overlooked: A teacher educator's confession. The Teacher Educator, 46(4), 265-273.

Pratiwi, H. Y., Ayu, H. D., \& Lestari, N. A. (2020). Developing Formative e-Assessment as a Stimulus to Improve the Quality of Mathematical Methods for Physics Learning Process. In Journal of Physics: Conference Series (Vol. 1491, No. 1, p. 012068). IOP Publishing.

Raaper, R., \& Brown, C. (2020). The Covid-19 pandemic and the dissolution of the university campus: Implications for student support practice. Journal of Professional Capital and Community, 5(3/4), 343-349. https://doi.org/10.1108/JPCC-06-2020-0032

Sabir, R. I., Akhtar, N., Bahadur, W., Sajjad, M. S., \& Abbas (2014). Impact of Distance Education on Student Performance: A Case of Allama Iqbal Open University. Middle-East Journal of Scientific Research, 21(3).472-476.

Semahegn, A., Torpey, K., Manu, A., Assefa, N., \& Ankomah, A. (2019). Adapted tool for the assessment of domestic violence against women in a low-income country setting. A reliability analysis. International Journal of Women's Health, 11, 65.

Shahzad, M. U. (2017). A literary review on distance education in Pakistan and future possibilities. Pakistan Journal of Distance \& Online Learning, 3, 85-102. 
Simonson, M., \& Seepersaud, D. J. (2019). Distance education: Definition and glossary of terms (4th ed.): IAP.

Simonson, M., Smaldino, S., \& Zvacek, S. M. (Eds.). (2014). Teaching and learning at a distance: Foundations of distance education. IAP.

Strauss, A., \& Corbin, J. (1994). Grounded theory methodology. Handbook of Qualitative Research, 17, 273-85.

Taylor, L. (2009). Developing assessment literacy. Annual Review of Applied Linguistics, 29, 21-36.

Yamtim, V., \& Wongwanich, S. (2014). A study of classroom assessment literacy of primary school teachers. Procedia-Social and Behavioral Sciences, 116, 2998-3004. 